\title{
The Attorney Misconduct Exception to the Work Product Doctrine
}

\author{
G. Michael Halfenger $\dagger$
}

The work product doctrine protects from discovery materials prepared in anticipation of litigation by a party or that party's attorney or representative. ${ }^{1}$ The doctrine creates a qualified privilege. ${ }^{2}$ Specifically, if the requested items do not reveal the mental impressions of their creator, they may be subject to discovery after the requesting party shows a "substantial need" and the inability, "without undue hardship, to obtain the substantial equivalent of the materials by other means." "The doctrine is designed to protect the adversary system by creating a "zone of privacy" in which an attorney may prepare her case. Recently, some courts have narrowed this zone of privacy with an attorney misconduct exception to the work product doctrine. This exception permits disclosure of work product in circumstances where the materials are generated in connection with attorney misconduct. The client need not be involved in the misconduct.

This Comment explains the role an attorney misconduct exception should perform and provides an approach for determining when the exception should apply. It also presents a guide for courts applying the exception beyond the limited contexts courts have considered to date. This proposal would require courts to order disclosure of work product in two sets of circumstances. The first is where attorney conduct violates a law or an accepted norm of professional conduct and the materials created by the attorney misconduct are "tainted," in the sense that they contain informa-

$\dagger$ B.A., Lawrence University, 1988; J.D. Candidate 1991, The University of Chicago.

1 FRCP 26(b)(3).

2 The work product doctrine is not so much a privilege that protects the parties as a "protection" that is designed to benefit the adversarial system. See Hickman v Taylor, 329 US 495, 509-10 (1947). See also Sherman L. Cohn, The Work-Product Doctrine: Protection, Not Privilege, 71 Georgetown L J 917, 943 (1983).

3 This standard was codified in FRCP 26(b)(3), which allows discovery of "documents and tangible things" otherwise protected by the work product doctrine "only upon a showing that the party seeking discovery has substantial need of the materials in the preparation of the party's case and that the party is unable without undue hardship to obtain the substantial equivalent of the materials by other means."

- Moody v IRS, 654 F2d 795, 800 (DC Cir 1981). 
tion gathered through misconduct. The second is where attorney conduct violates a law or an accepted norm of professional conduct, disclosure of materials would serve to correct any information asymmetry caused by the misconduct, no other remedies will adequately rectify the effects of the misconduct, and disclosure would not adversely impact other parties.

Section I examines the work product doctrine from its origin in Hickman v Taylor to its incorporation in Federal Rule of Civil Procedure (FRCP) 26, and briefly describes the case law concerning the attorney misconduct exception. Section II describes the work product doctrine's role in facilitating a well-functioning adversary system and examines the effect of attorney misconduct on the policies underlying the adversary system. Finally, Section III proposes an application of the misconduct exception that is consistent with the policies underlying the work product doctrine, and suggests other types of cases to which the exception should apply.

\section{The Work Product Doctrine and the Misconduct EXCEPTION}

\section{A. An Overview of the Work Product Doctrine}

The Supreme Court first announced the work product doctrine in Hickman $v$ Taylor. ${ }^{5}$ In Hickman, a party sought copies of witness statements obtained by the opposing party's counsel in anticipation of litigation. ${ }^{6}$ The attorney who requested the statements admitted that he wanted them "only to help prepare himself to examine witnesses and to make sure that he ha[d] overlooked nothing." The Supreme Court held that the statements were the work product of the lawyer who had obtained and prepared them and were not discoverable. The statements were protected because the requesting attorney had not shown that the information in the materials was both essential to his case and not otherwise available. ${ }^{8}$

The Court reasoned that allowing attorney work product to be discovered would adversely affect the proper preparation of the client's case. Such a rule would jeopardize the just outcomes of controversies, primarily because of the resultant disincentive to use

\footnotetext{
- 329 US 495 (1947).

- Id at 498-99.

7 Id at 513 .

(Id at 509, 512-13.
} 
documents in preparing the case for trial. ${ }^{9}$ The Court implied that materials tending to reveal the attorney's mental impressions or legal strategies might demand even absolute protection. ${ }^{10}$ The Court therefore created a rule that allows for the discovery of needed facts while substantially protecting the legal strategies of the attorney. The Hickman work product doctrine has been incorporated into the Federal Rules of Civil Procedure as FRCP 26.11

The work product doctrine protects both "ordinary" and "opinion" work product. Ordinary work product, materials prepared in anticipation of litigation ${ }^{12}$ by the party or her representative $^{18}$ that do not tend to reveal mental impressions, is discoverable only if (1) substantial need for the materials exists ${ }^{14}$ and (2) equivalent materials cannot be obtained elsewhere without undue hardship. ${ }^{16}$ Opinion work product, information that reveals strategies or mental impressions, has a more stringent discovery standard. ${ }^{16}$ Some courts have held that no showing of necessity can

- Id at 510-11.

10 Specifically, the Court stated, "When Rule 26 and the other discovery rules were adopted, this Court and the members of the bar in general certainly did not believe or contemplate that all the files and mental processes of lawyers were thereby opened to the free scrutiny of their adversaries." Hickman, 329 US at 514.

"FRCP 26(b)(3) provides: "[T] he court should protect against disclosure of mental impressions, conclusions, opinions, or legal theories of another attorney or other representative of a party concerning the litigation."

${ }^{12}$ Id. For discussions of what constitutes "in anticipation of litigation," see John William Gergacz, Attorney-Corporate Client Privilege § 7-18 to § 7-24 (Garland, 1987); John William Gergacz, Attorney-Corporate Client Privilege 103-13 (Garland, Supp March 1989) ("Supplement"); Edna Selan Epstein, et al, The Attorney-Client Privilege and the WorkProduct Doctrine 68-75 (ABA, 1983).

1s FRCP 26(b)(3). For a discussion of who may be considered a party's "representative," see Epstein, The Attorney-Client Privilege and the Work Product Doctrine at 75-76 (cited in note 12).

14 FRCP 26(b)(3). The substantial need test is met if no alternative means of obtaining the information exists. See Xerox Corp. $v$ IBM Corp., 64 FRD 367, 389 (S D NY 1974). That obtaining the information in another manner would be more expensive is usually not considered a substantial need. See Epstein, The Attorney-Client Privilege and the Work Product Doctrine at $79-80$ (cited in note 12) and cases cited therein.

1s FRCP 26(b)(3). For a discussion of this requirement, see Epstein, The AttorneyClient Privilege and the Work Product Doctrine at $80-82$ (cited in note 12). When witness statements are sought, the critical factor is whether the witness is available for interviewing by the party seeking discovery. United States v Chatham City Corp., 72 FRD 640, 643-44 (S D Ga 1976). Additional costs imposed by alternative methods of obtaining information probably do not constitute "undue hardship," unless those costs are substantial. Compare Arney v George A. Hormel \& Co., 53 FRD 179, 181 (D Minn 1971) ("the costs or inconvenience of taking the deposition is not in itself sufficient showing to meet the 'undue hardship' requirements of the rule"); with Jarvis, Inc. $v$ AT\&T Co., 84 FRD 286, 293 (D Colo 1979) ("we question the practicality and reasonableness of forcing movants to depose the 1500 persons .....").

${ }^{16}$ The line between opinion work product and ordinary work product is not clear. John William Gergacz suggests that "work product is better envisioned as a scale or continuum 
overcome protection of opinion work product. ${ }^{17}$ Although the Supreme Court declined to decide that issue in Upjohn $v$ United States, Upjohn suggests that a very high (if not absolute) level of protection is to be afforded such materials. ${ }^{18}$

\section{B. The Misconduct Exception}

Although the case law is scarce, ${ }^{19}$ a recent line of cases suggests that attorney misconduct may sometimes vitiate the work product doctrine's protection. Courts that recognize this exception reason that since the main policy underlying the work product doctrine is the protection of the adversary system, ${ }^{20}$ work product generated outside the proper scope of that system should be denied protection.

The Court of Appeals for the District of Columbia Circuit was the first to recognize an attorney misconduct exception to the work

with pure opinion work product on one end and pure ordinary work product on another." Gergacz, Attorney-Corporate Client Privilege at $\$$ 7-28 (footnote omitted) (cited in note 12); see also Jones v McKinley Community Services, 1989 US Dist LEXIS 14312, *4 (N D III). Ordinary work product may include indices of documents and data from test results, see Pearl Brewing Co. $v$ Joseph Schlitz Brewing Co., 415 F Supp 1122, 1138 (S D Tex 1976), and, perhaps, documentation of witnesses' statements that contains little information as to the attorney-questioner's strategies. See In re Grand Jury Investigation, 599 F2d 1224, 1230-31 (3d Cir 1979); Jones, 1989 US Dist LEXIS 14312 at *7 (tape recordings of interviews with witnesses are not absolutely immune from discovery, because "[i]t is unlikely that [counsel] developed and recorded trial strategy while interviewing these individuals. It is also unlikely that he shared with these witnesses his mental impressions of their testimony and demeanor."). Documents that tend to disclose the attorney's strategies, such as an attorney's evaluation of data or the viability of the case, as well as some attorney documentation of witness statements, have been considered opinion work product. See Upjohn Co. v United States, 449 US 383, 399 (1981).

17 See, for example, Duplan Corp. v Moulinage et Retorderie de Chavanoz, 509 F2d 730, 734 (4th Cir 1974); In re Grand Jury Proceedings, 473 F2d 840, 848 (8th Cir 1973); In re Grand Jury Investigation, 412 F Supp 943, 949 (E D Pa 1976). But see Duplan Corp. $v$ Deering Milliken, Inc., 397 F Supp 1146, 1158-59 (D SC 1974); In re Grand Jury Investigation, 599 F2d at 1231; Xerox, 64 FRD at 381.

${ }^{18}$ In Upjohn the government had requested discovery of documents containing responses to questionnaires sent by Upjohn's counsel to certain of its managers, as well as counsel's notes reffecting his mental impressions for interviews of those managers and other employees. The government argued that it was unable to obtain the needed factual information elsewhere without severe hardship (if at all), because the "interviewees are scattered across the globe and [] Upjohn has forbidden its employees to answer questions it considers irrelevant." 449 US at 399 . However, the Court found that the government had not made a sufficient "showing of necessity and unavailability by other means ... to compel disclosure." Id at 401-02.

19 Wilson v Lamb, 125 FRD 142, 143 (E D Ky 1989).

${ }^{20}$ This issue is discussed further in Section II. 
product doctrine in Moody $v$ IRS. ${ }^{21}$ In Moody, an attorney for the IRS met ex parte with a federal district court judge to discuss the enforcement of a summons. The court allowed discovery of the attorney's memorandum detailing the meeting, reasoning that because the purpose of the work product doctrine is to protect the adversary system, "[i]t would indeed be perverse . . . to allow a lawyer to claim an evidentiary privilege to prevent disclosure of work product generated by those very activities the privilege was meant to prevent." 22 In effect, the use of the work product doctrine in this case to prevent disclosure would provide an incentive for misconduct. ${ }^{23}$ Drawing an analogy to the well-established exception that the work product doctrine cannot be used to conceal a client's crime or fraud, ${ }^{24}$ the court noted that an attorney likewise should not "be able to exploit the privilege for ends outside of and antithetical to the adversary system ...."25

The Moody court noted, however, that the work product doctrine might still protect documents tainted by attorney misconduct under some circumstances. ${ }^{26}$ The court remanded to the district court to determine whether the attorney's conduct violated professional standards and, if so, whether such violation vitiated the work product protection. ${ }^{27}$ With regard to the latter, the court instructed the trial court to consider all the circumstances of the case, as well as certain specific factors. These factors are: (1) whether and to what extent the documents are "tainted" by the misconduct; ${ }^{28}$ (2) whether disclosure (rather than other sanctions) is an appropriate remedy in addressing the misconduct; ${ }^{29}$ and (3) whether the policy favoring disclosure outweighs the client's legitimate interests in secrecy. ${ }^{30}$

21654 F2d 795 (DC Cir 1981).

22 Id at 800 (footnote omitted). See also id at $800 \mathrm{n} 16$.

23 Id at 800 .

${ }^{24}$ See also In re International Systems and Controls Corp. Securities Litigation, 693 F2d 1235, 1241-42 (5th Cir 1982); In re John Doe Corp., 675 F2d 482, 492 (2d Cir 1982).

${ }^{25}$ Moody, 654 F2d at 800 (footnote omitted).

20 Id at 801 .

27 Id.

${ }^{28}$ Id at 801 n 20 ("What constitutes 'taint,'of course, must be decided in the context of each case. It may be that portions of documents, rather than whole documents, will be deemed 'tainted' and thus 'releasable." ").

29 Id at $801 \& \mathrm{n} 23$.

${ }^{30}$ See id at $801 \mathrm{n} 24$ :

A client's interest in non-disclosure would be illegitimate, of course, if he knowingly instigated or participated in the conduct which constituted the breach of duty. In some cases, the extent to which a client should be allowed to benefit from unprofessionally 
The Moody analysis has been applied in a series of cases involving clandestine taping of witnesses. In Parrott $v$ Wilson, the defendants moved for discovery of tape recordings that the plaintiff's attorney had secretly made during conversations with two non-party witnesses. ${ }^{31}$ Although this conduct was not illegal, the court found that such recordings violated an American Bar Association rule of professional responsibility. ${ }^{32}$ Citing Moody, the Eleventh Circuit upheld disclosure and rejected the argument that the tapes were protected by the work product doctrine. ${ }^{33}$ Specifically, the court maintained that disclosure was an appropriate remedy because "the evidence sought was generated directly by the attorney's misconduct." ${ }^{34}$ The witnesses testified that they would not have consented to the interviews had they known of the taping. ${ }^{35}$

Similarly, in Wilson $v$ Lamb ${ }^{36}$ defendants sought production of tapes made at a meeting (which took place before the action had been filed) between plaintiff, his counsel, and two individuals employed by a defendant. The court found that the tapes had been made clandestinely and that the employees would not have taken part in the meeting had they been aware of the taping. ${ }^{37}$ The court did not expressly apply the Moody factors but did rely on Parrott and Moody in holding that any work product protection was vitiated because the tapes would not have existed but for the misconduct. ${ }^{38}$ The court also noted that "the defendants could obtain the tape through a request from [the employees] to the plaintiff under Fed.R.Civ.P. 26(b)(3)." "39 Thus, no purpose would be served by further delaying the inevitable result-the defendants would get those tapes.

obtained information may also be questioned; such benefits, in some cases, may not be deemed a "legitimate" secrecy interest.

31 707 F2d 1262, 1270-71 (11th Cir 1983).

32 Id at 1271.

${ }^{33}$ In upholding the disclosure order, the court stated:

We are mindful of the client's interest in protecting against the disclosure of work product. However, we are unable to say that the disclosure in this case "traumatize[d] the adversary process more than the underlying legal misbehavior" . . . The only discernible effect of the disclosure was that the depositions of [the witnesses] commenced with the playing of the taped conversations. We thus hold that whatever work product privilege might have existed was vitiated by counsel's clandestine recording of conversations with witnesses.

Id at 1271-72 (quoting Moody, $654 \mathrm{~F} 2 \mathrm{~d}$ at 801 (footnotes omitted)).

${ }^{34}$ Id at 1271-72 $\mathrm{n} 20$ (emphasis in original).

ss Id.

36 Wilson, 125 FRD at 143.

${ }^{37}$ Id.

38 Id.

39 Id at 143-44. 
Haigh v Matsushita Elec. Corp. of America, ${ }^{40}$ another clandestine taping case, extended the attorney misconduct exception the farthest. In Haigh, the attorney's misconduct did not clearly violate any written ethical rule. Moreover, the court stated that it did not have to consider whether the tapes were needed by the moving party. ${ }^{41}$ Haigh, whose action was for wrongful dismissal, had taped his conversations with individuals whom he thought might have information relevant to his case. Haigh made these tapes without the explicit advice of counsel and without the individuals' consent or knowledge. ${ }^{22} \mathrm{He}$ argued that the tapes were protected as work product because he had consulted counsel about his belief that defendants were trying to force him out of the company. ${ }^{43}$ Haigh delivered the cassette tapes to his counsel shortly after each conversation. His counsel subsequently reviewed the tapes and used them to prepare the complaint and discovery requests. ${ }^{44}$

The trial court pointed out that FRCP 26(b)(3) extends to materials prepared by the party himself, but applied the Moody line of cases (which dealt only with materials generated by counsel) and held that the work product protection had been vitiated. ${ }^{45}$ The court stated that it "need not delve into questions of 'substantial need,' 'undue hardship,' or 'substantial equivalent' " because courts "have come to realize that in some circumstances, a lawyer's unprofessional behavior may vitiate the work product privilege." "46 The court acknowledged both that Haigh had initiated the tapings on his own and that he was not bound by the ethical strictures that bind attorneys. ${ }^{47}$ However, because Haigh had turned the tapes over to his counsel almost immediately, the court found that Haigh and his counsel "fell into a pattern of conduct" that constituted counsel's "active encouragement and affirmative support" for activities that, if carried out by counsel, would be unethical. ${ }^{48}$ The attorney's "active encouragement" was thus sufficient to vitiate the work product protection. ${ }^{99}$ Notably, if Haigh

\footnotetext{
10 676 F Supp 1332 (E D Va 1987).

11 Id at 1357.

12 Id at 1356.

43 Id.

14 Id at 1357.

16 Id at 1357-59.

16 Id at 1357 (quoting Moody, 654 F2d at 800).

47 Id at 1358 .

48 Id at 1359.

12 The court noted that "[t]here is, and can be, no bright line to determine when this point [where acquiescence ceases to be passive and noncommittal, and becomes active en-
} 
had not retained counsel, there would have been no misconduct to vitiate the privilege; however, "when [a client] retains [an] attorney, he also retains the responsibilities imposed on that attorney."."

Although these cases have a limited scope (all but Moody deal with clandestine tapings), they suggest that any document that would not have been generated but for some attorney misconduct might be discoverable under the exception. Haigh expands the exception to some conduct undertaken by the client himself.

\section{The Adversary System, the Work Product Doctrine, and AtTORNEY MisconduCT}

In developing the misconduct exception, the Moody court reasoned that the work product doctrine should not shield behavior that undermines the adversary system. The court failed to explain, however, how protecting information gained through attorney misconduct harms the adversary system. In an attempt to justify the attorney misconduct exception, this Section discusses the functions of the adversary system and the role the work product doctrine plays in protecting that system.

\section{A. The Adversary System and Discovery Rules}

The judicial system performs four primary functions: it creates or alters legal rules to govern behavior, it enforces legal rules to influence future behavior (through accurate application of rules and levying of sanctions), it transfers wealth between parties, ${ }^{51}$ and it legitimates the broader system of government by providing a forum in which people may vindicate their rights and ensure that legal rules are applied equally. Historically, parties came before the court with little information about the other side's case. ${ }^{52} \mathrm{~A}$ strict adversary system, in which no information is exchanged between the parties before appearing in court, imposes severe costs on the parties, on society, and on the judicial system. Allowing information to be available to only one side, whether because it happened to be in that party's control or because one side had greater re-

couragement and affirmative support] is reached. . . . Here, the Court is certain that that point has been crossed." Id.

so Id.

51 The first three functions are suggested by Frank H. Easterbrook in Insider Trading, Secret Agents, Evidentiary Privileges, and the Production of Information, 1981 S Ct Rev $309,359$.

${ }^{52}$ See Cohn, 71 Georgetown $\mathrm{L} \mathrm{J}$ at 917-18 (cited in note 2). 
sources to expend, would allow that party to hide information detrimental to its interests or beneficial to those of the opposing party.

These restraints on information impose three costs. First, they make it difficult for the court to apply accurately the legal rule to the facts because some of the relevant facts will be withheld from the court. Such inaccurate application of legal rules results in less effective deterrence of behavior. ${ }^{53}$ Some individuals would not perform socially beneficial conduct because of the possibility that sanctions would be erroneously applied; ${ }^{54}$ others might be more likely to perform prohibited conduct. ${ }^{\mathrm{ss}}$ Second, the restraint would be socially inefficient, because some parties would be forced to expend considerable resources to duplicate information that the opposing party could furnish at low cost. Third, assuming that certain classes of parties are more likely to possess relevant information, ${ }^{56}$ such a system produces systemic biases in the enforcement of legal norms.

The American judicial system attempts to minimize these costs with liberal discovery rules and sanctions for violating those rules. Liberal discovery rules facilitate equal access to facts in an opponent's possession, thus correcting the problem of information fortuitously available to only one party. The discovery rules make it likely that all relevant facts will be presented to the court. A court is thus better able to accurately apply the legal rule to the facts. Lastly, liberal discovery rules mean that no party is forced to expend vast resources to obtain facts from other sources when the facts are held by the opposition, eliminating the systemic bias resulting from the ability to hide information. One disadvantage of a liberal discovery system is that it decreases the parties' incentives to independently seek out all the relevant facts and theories.

s3 See Easterbrook, $1981 \mathrm{~S} \mathrm{Ct} \mathrm{Rev} \mathrm{at} 359$ (cited in note 51).

s4 Although an individual can always come forward with exculpatory information in her possession, sometimes one knows that another party has exculpatory information. Consider a breach of contract case in which both parties claim that the other breached. If the actual breaching party is able to withhold necessary information, resulting in the sanction of the innocent party, parties will have diminished incentives to enter into socially beneficial contracts, or, alternatively, greater incentives to take socially detrimental self-help actions.

${ }^{s s}$ See Louis Kaplow and Steven Shavell, Legal Advice About Information to Present in Litigation: Its Effects and Social Desirability, 102 Harv L Rev 567 (1989). The level of sanctions might be increased to offset these inaccuracies. However, increased sanctions combined with inaccurate application of the legal rules will deter beneficial conduct in situations where, as discussed in note 54 , the court must decide which of two parties violated a legal norm.

so Examples might include employers' information about workplace conditions, manufacturers' information about design defects, and consumers' information about their use of allegedly malfunctioning products. 
Judicial sanctions attempt to ensure that this liberal discovery regime is not used inconsistently with its purpose-equalizing access to information..$^{67}$ State and federal laws, court rules, and bar codes of conduct all help define the sphere in which parties may legitimately develop their cases. ${ }^{58}$ Sanctions both fence in the adversary system and further the goal of reaching accurate results. ${ }^{59}$ Parties who abuse the discovery process by making overly burdensome requests or by producing documents in an untimely or inappropriate manner, for example, raise the costs of the litigation to the opposing party. ${ }^{60}$ Such abuse introduces inefficiencies into the factfinding process ${ }^{61}$ and forces some parties out of the judicial system and into often unfavorable, and socially undesirable, settlements. ${ }^{\text {e2 }}$

B. The Function of the Work Product Doctrine and the Role of the Misconduct Exception

The work product doctrine attempts to balance the benefits of the adversary system and the benefits of liberal discovery rules.

${ }^{87}$ See also Charles B. Renfrew, Discovery Sanctions: A Judicial Perspective, 67 Cal L Rev 264, 264-65 (1979).

ss "The power to punish for contempts ... is essential to the preservation of order in judicial proceedings, and to the enforcement of the judgments, orders, and writs of the courts, and consequently to the due administration of justice." Ex parte Robinson, 86 US 505,510 (1873) (emphasis added).

${ }^{59}$ Examples of judicial sanctions include: contempt sanctions under 18 USC $\S 401$ (1988); payment of unreasonably increased costs under 28 USC § 1927 (1988); expenses under FRCP 11 for pleadings or motions that are unfounded or used to harass; and, for discovery abuses, "such orders . . . as are just," including orders that certain facts be taken as established, that the offending party not raise certain claims or defenses, striking pleadings, or dismissing the offending party's case with prejudice under FRCP 37(b)(2), see $\mathrm{Na}$ tional Hockey League v Metropolitan Hockey Club, Inc., 427 US 639, 643 (1976) (upholding order of dismissal) and General Atomic Co. v Exxon Nuclear Co., Inc., 90 FRD 290, 307 (S D Cal 1981) (taking claims as established). In addition, any court that has the power to admit attorneys to practice law in a particular jurisdiction has the power to censure, suspend, or disbar, Mullen v Canfield, 105 F2d 47, 48 (DC Cir 1939); and any interested person may institute disciplinary proceedings against an attorney for conduct outside the legitimate boundaries of the judicial system. See generally Comment, Sanctions Imposed by Courts on Attorneys Who Abuse the Judicial Process, 44 U Chi L Rev 619, 639 (1977). Examples of sanction-like powers available to individual parties include causes of action for malicious prosecution, wrongful civil proceedings, and abuse of process. See W. Page Keeton, ed, Prosser and Keeton on the Law of Torts, 870-900 (West, 5th ed 1984).

${ }^{60}$ See Frank H. Easterbrook, Discovery as Abuse, 69 BU L Rev 635, 636-38 (1989) (arguing that judicial sanctions cannot adequately deter discovery abuses); Note, Discovery Abuse Under the Federal Rules: Causes and Cures, 92 Yale L J 352, 355-60 (1982).

${ }^{61}$ See generally Note, 92 Yale I $J 352$ (cited in note 60).

${ }^{62}$ Easterbrook, 69 BU L Rev at 637 (cited in note 60). Settlements may result in social losses if they reflect the desire to avoid litigation costs more than the efficient level of damages necessary to deter detrimental conduct. 
Specifically, under FRCP 26 a party may discover relevant materials from an opponent as long as those materials were not prepared in anticipation of litigation. This rule equalizes the undesirable results of arbitrary distributions of information between the parties and reduces the inefficiency that would result if one party had to expend vast resources to obtain information available to her opponent at little cost.

The work product doctrine is one important exception to this general principle. By protecting attorneys' mental impressions, it preserves a zone of privacy in which parties can develop their strategies. The Hickman Court argued that such protection furthered the interests of both the client and of justice. ${ }^{63}$ If the judicial system is to rely on attorneys to shape cases and develop novel legal theories, it must offer adequate incentives for them to do so. Protecting their work product, particularly when that work product reveals strategies, supplies those incentives. ${ }^{64}$ If work product were not protected, attorneys would simply not put these theories in a discoverable form. Developing sophisticated case strategies and legal theories without putting pen to paper is certainly inefficient, if not impossible.

The Rule 26 requirement that the requesting party show substantial need and undue hardship to obtain ordinary work product best captures the balance established by the work product doctrine between the need to provide incentives to gather relevant facts and formulate legal theories, and the need to equalize access to relevant information. All work product documents prepared in anticipation of litigation are likely to reveal at least some minor aspect of the attorney's strategies. This policy of providing incentives to gather information and formulate strategies does not protect all work product from disclosure, however. For example, consider a survey conducted to determine, for the purpose of litigation, whether there is likelihood of confusion between two trademarks. ${ }^{65}$

63 Hickman, 329 US at 511. The Court feared that without a zone of privacy to protect case development, "[i]nefficiency, unfairness and sharp practices would inevitably develop in the giving of legal advice." Id.

64 Both the majority and the concurrence in Hickman feared that if witness statements taken by the attorney were discoverable, those statements would be used at trial to unfairly discredit the witnesses. Id at 517 (Jackson concurring) ("Counsel producing his adversary's 'inexact' statement could lose nothing by saying, 'Here is a contradiction, gentlemen of the jury. I do not know whether it is my adversary or his witness who is not telling the truth, but one of them is not." "). See also id at 513 (majority opinion).

os Likelihood of confusion is an element of the cause of action for trademark infringement under the Lanham Act, 15 USC § 1127 (1988). 
Such a survey would probably not qualify for heightened protection as opinion work product. Yet by examining the questions asked in the survey, one might deduce some of the attorney's strategies. For example, the questions may suggest that the attorney intends to show that her client's mark had secondary meaning. ${ }^{B 6}$ Nevertheless, if this were the only such survey available, it might be discoverable, if the requesting party could show the requisite need and harm resulting from lack of access to this information. Assuming it is nearly impossible to replicate the survey, allowing its discovery may well outweigh the relatively slight effect on incentives to form strategies. Once the litigation has begun, the work product doctrine shields information gathered by attorneys unless that information is both very costly for the other side to obtain and can be revealed in a form that does not substantially disclose strategies.

Although the work product doctrine was created in Hickman to protect incentives to gather information and thus serve the interests of justice and of the client, the Court was not concerned with protecting all avenues of information-gathering. Rather, the Court emphasized the need to protect work product "prepared or formed ... in the course of [the attorney's] legal duties." Court recognized that lawyers have historically been considered officers of the court, "bound to work for the advancement of justice while faithfully protecting the rightful interests of his clients." The work product doctrine should promote only those avenues of factfinding and legal theorizing that are allowed by the rules governing attorney conduct.

Information-gathering techniques involving attorney misconduct interfere with the advancement of justice and should thus be deterred. Forcing the disclosure of materials containing information obtained through misconduct is an effective deterrent to that misconduct. In Hickman, the Court maintained that denying attorneys the fruits of their illegitimate practices would deter such conduct. ${ }^{69}$ The attorney misconduct exception ensures that attorneys will not reap such fruits.

${ }^{60}$ Trademarks with secondary meaning, or source indicating significance, are afforded greater protection than those without. See Beverly W. Pattishall and David Craig Hilliard, Trademarks 42 (Matthew Bender, 1987).

82 Hickman, 329 US at 510 (emphasis added).

${ }_{68}$ Id.

89 Id at 511-13. 


\section{Applying the Atrorney Misconduct Exception}

In creating the attorney misconduct exception, the Moody court reasoned that because the work product doctrine's purpose is to protect the adversary system, an attorney should not be able to use the doctrine "for ends outside of and antithetical to" that system. ${ }^{70}$ But the court recognized that the doctrine might protect some documents related to the misconduct. Specifically, the court directed the district court to consider: (1) whether the documents were tainted by the misconduct, (2) whether disclosure was an appropriate remedy in addressing the misconduct as opposed to other sanctions, and (3) whether the policy favoring disclosure outweighed the client's legitimate interests in secrecy. ${ }^{71}$ Unfortunately, the Moody court explained neither how these factors relate to the work product doctrine nor more generally, how they further the purposes of the adversary system. ${ }^{72}$

This Section attempts to accomplish these tasks. It analyzes each of the Moody factors and explains how they should be applied in order to further the policies underlying the work product doctrine. The Section concludes that the attorney misconduct exception should apply whenever attorney misconduct violates a law or an accepted norm of professional conduct and the materials created by the misconduct are "tainted," in the sense that they contain information gathered through misconduct. Furthermore, the exception should apply whenever the attorney violates a law or an accepted norm of professional conduct, disclosure of the materials will serve to correct an information asymmetry caused by the misconduct, no other remedy will adequately redress the effects of the misconduct, and disclosure will not have an adverse impact on other parties.

7o Moody, 654 F2d at 800 .

71 Id at 801.

72 Gergacz has suggested one approach for applying the attorney misconduct exception. He would first determine whether the attorney's conduct violates any formal ethical standard (for example, ABA Model Code of Professional Conduct and state ethical codes), "and if not, whether the conduct may still be described as falling below that which would be expected of an attorney." Gergacz, Supplement at 128 (cited in note 12). Second, he would evaluate the connection between the attorney's misconduct and the work product in question and not apply the exception "[i]n the absence of a sufficiently close relationship." Id at 129. Lastly, he would determine how the misconduct affected the policies underlying the work product doctrine in terms of the seriousness of the misconduct and the appropriateness of the remedy. Id at 130 . 
A. What Constitutes Attorney Misconduct

Not all attorney misconduct will justify invoking the misconduct exception, but the Moody court did not distinguish particular types of misconduct in defining the exception. Because the work product doctrine protects attorney strategies while allowing for equal access to information regarding the facts of the case, the exception should only extend to misconduct that puts other parties at a disadvantage in the control of information relevant to the case. Such a disadvantage may result when an opponent either obtains information by illegitimate means or hides information to evade discovery orders. Courts should consider applying the exception to both types of misconduct.

Although Moody directed the lower court on remand to determine whether there was a violation of "professional standards,"73 the Haigh court applied the exception where there was no clear violation of any formal ethical standard. To adequately protect the zone of privacy created by the work product doctrine, however, only attorney conduct that violates a law, an ABA or state bar association conduct code, or a written court rule should constitute misconduct for purposes of the exception. ${ }^{74}$ Although applying the exception to conduct seen as unethical, but not literally proscribed by law or by the ethics rules, might deter additional undesirable conduct, such application has significant costs. Specifically, to the extent that attorneys are uncertain of which types of conduct will be regarded as illegitimate, there will be a marginal chilling effect on an attorney's conduct. ${ }^{75}$ This chilling effect, in turn, raises the cost of legitimate information-gathering and case development, the protection of which is the work product doctrine's central purpose.

Broad use of an unclear attorney misconduct exception might also produce significant social costs from increased litigation over whether conduct falls within the exception and which types of information must be relinquished. The misconduct exception might become yet another means of delaying litigation, rather than a remedy for certain types of misconduct. However, if the exception is applied only to violations of established rules, the chilling effect, the costs of increased litigation, and the potential for abuse of the exception are minimized.

${ }^{73} 654$ F2d at 801.

74 See Gergacz, Supplement at 128 (cited in note 12).

${ }^{3}$ But see Renfrew, $67 \mathrm{Cal} \mathrm{L} \mathrm{Rev} \mathrm{at} 274$ (cited in note 57) ("Judicious use of sanctions will not [] significantly deter attorneys from the zealous representation of clients."). 
B. Types of Materials Subject to the Exception

The Moody court instructed the trial court to consider whether the documents were "tainted" by the misconduct, ${ }^{76}$ without explaining the term. This Comment argues that documents generally should be considered tainted when they include information obtained through attorney misconduct. The documents in Moody, for example, were tainted because they contained information about the discussion at the ex parte meeting which the opposing party had a right to attend. Documents that are so tainted should be subject to the misconduct exception. In addition, documents that contain information that was not obtained through misconduct may be subject to disclosure under the exception. Such documents should be disclosed if this is the best means to correct an information advantage caused by attorney misconduct. This discussion demonstrates that this approach is consistent with the policies of the work product doctrine and then applies the approach.

1. Policies underlying the approach.

Misconduct often affords the party access to information that is extremely costly for the opponent to obtain (since it may be obtained only through punishable misconduct). Similarly, misconduct that obstructs the other party's access to information may allow the offending party to increase the opponent's costs of obtaining information to which she has a right under the discovery rules. Where discovery of the documents held by the misbehaving party would correct the resulting cost asymmetries, application of the exception is consistent with the policies of the work product doctrine.

The work product doctrine should not protect information that can be obtained only through means that the other party is prohibited by law from using. When information is gathered through misconduct or when misconduct obstructs the gathering of information, the allocation of information among the parties may deviate from the allocation envisioned by the policies underlying the work product doctrine. The work product doctrine protects information gathered after the litigation has commenced, especially when that information tends to reflect the parties' strategies. Information gathered after the onset of the litigation is presumed to be available to all parties. This presumption may not hold up, 
however, when information has been obtained through misconduct. Illegal or unscrupulous means may be the only (or only cost-effective) way to obtain certain information. The misbehaving party is able to obtain information others either cannot obtain or cannot obtain at a reasonable cost. Thus, at a minimum, the exception should apply to documents with information obtained through misconduct that the other side cannot legally obtain. ${ }^{77}$

\section{Applying the exception to tainted materials.}

The attorney misconduct exception should apply to all materials containing information obtained through misconduct unless there is an equally effective means of procuring the same information. The tape cases support the proposition that the exception can be applied even where similar information is readily available through other means. In Parrott and Wilson, for example, the witnesses whose conversations were taped were available. ${ }^{78}$ In these cases, however, the trial judge probably did not want to force the innocent party to obtain the information through normal channels. In addition, the tapes at issue were unlikely to contain much insight into the attorney's impressions and were otherwise easily obtainable. In these cases the exception was probably used as a discovery "short cut" which is hardly objectionable.

For the misconduct exception to have any real bite, it must apply even when disclosure of the attorney's mental impressions results. Consider an attorney who represents the plaintiff in a tort case against her employer, and who interviews employees while purporting to be a neutral party, in violation of Model Rule 4.3, or, perhaps, Rule 4.2.79 The attorney makes notes on the interviews, and the employer seeks those notes under the misconduct exception. The court, after examining the notes in camera, should allow disclosure to the extent necessary to provide the employer with full information as to what was said at the interviews. In such a case, some of the attorney's mental impressions may be disclosed. The Hickman Court, however, created the work product doctrine in part to guard against the use of "sharp practices" in developing

77 Or cannot legally obtain at a reasonable cost.

${ }^{78}$ Parrott v Wilson, 707 F2d 1263, 1272 (11th Cir 1983); Wilson v Lamb, 125 FRD 142, 143-44 (E D Ky 1989).

${ }^{79}$ Model Rules of Professional Conduct Rule 4.2 (communication with person represented by counsel), Rule 4.3 (communication with person not represented by counsel), reprinted in Thomas D. Morgan and Ronald D. Rotunda, 1990 Selected Standards on Professional Responsibility 154, 155 (Foundation, 1990). 
cases by protecting attorney strategies. ${ }^{80}$ Protection of attorney strategies is but a means to the end of promoting the thorough development of cases within the legitimate constraints of the judicial system. There is no reason to protect such strategies where the protection would create incentives to use unethical means in case development. $^{81}$

Applying the exception, however, a court should order the materials redacted to the extent that they reveal mental impressions unrelated to the misconduct that produced the information. For example, if the attorney had written a memorandum containing information unlawfully acquired, and the document also contained information unrelated to the interviews, only those parts of the memorandum relating to the interviews should be disclosed. ${ }^{82}$ Forcing disclosure of information unrelated to the misconduct might provide additional deterrent effects, but it would also create undesirable incentives for the misbehaving attorney to avoid putting any case strategies in material form, contrary to the policies underlying the work product doctrine.

Where documents contain only information gathered through misconduct, a court should order disclosure even if an equally or more effective means of obtaining the same information is available. For example, if in Moody a transcript had been made of the ex parte meeting, the court should have ordered disclosure of the attorney's memorandum regarding that meeting. In such a case, the policies of the work product doctrine simply would not extend to the memorandum because the information was not obtained through legitimate means. ${ }^{83}$ Although the errant party may not have an information advantage because equally effective means of obtaining the information is available and the use of other sanctions might be an effective deterrent to the misconduct, the purposes of the work product doctrine do not support applying the doctrine to shield such materials.

\section{Application to other materials.}

In the cases involving the attorney misconduct exception, the work product in question arguably would not have existed but for

so See note 63 .

81 See text at notes $22,25,67,68$.

82 This seems to be what the Moody court had in mind when it stated, "It may be that portions of documents, rather than whole documents, will be deemed 'tainted' and thus 'releasable.'" Moody, 654 F2d at 801 n 20.

s3 See text at note 67 . 
the misconduct. ${ }^{84}$ Under the approach proposed by this Comment, the misconduct exception should, in some circumstances, be applied to work product that would have existed even had there been no misconduct. The exception should also apply where disclosure will remedy misconduct that gives an attorney an information advantage by obstructing the opposing party's access to information.

Consider an attorney who delays production of documents pursuant to a discovery request and then produces 50,000 documents, gathered from several sources, in bundles which do not designate from which files the documents came. Such production violates FRCP 34(b), which allows the producing party the option of either producing documents as they are ordinarily kept or of organizing and labeling them to correspond to the request. ${ }^{85}$ Assume that the unethical attorney in this case had previously created an index to the documents, which was arranged in a manner that could reveal protected strategies (perhaps grouping documents keyed to certain witnesses). Because the index is arranged in this way, redaction would not be a feasible alternative. In such a case, the index should be produced under the exception. Parties are entitled to obtain production of documents organized in a certain manner. Producing the documents in violation of FRCP 34 puts the receiving party in an unfavorable position not foreseen by the rules. The misbehaving attorney's client may benefit from his misconduct, either from the delay necessary for the court to order a new production or a new index, or from the added costs to the other party. Where the unethical attorney already has an index to the documents, that index should be produced immediately under the exception, regardless of the fact that production may reveal otherwise protected mental impressions and that the index was not itself the product of misconduct.

Such production quickly remedies the disadvantage to the party receiving the documents. It also forces some of the costs of the unethical behavior onto the unethical attorney, in that some of her efforts inure to the benefit of the opposition. The client who paid the attorney to organize and index the documents will be less than pleased with the result, and this too provides a means of enforcing the rules of the adversary system.

When the attorney's misconduct has made her opponent's task of developing her case considerably more difficult, materials which can substantially correct that difficulty should be disclosed. The

\footnotetext{
s4 Haigh may be a possible exception. See text at notes 47-50.

ss FRCP 34(b).
} 
Hickman Court maintained that justice would be better served by allowing parties the scope to develop their cases free from the intrusions of other parties. ${ }^{86}$ Misconduct that obstructs case preparation is a form of intrusion. As such, the work product doctrine should not protect an attorney who acts illegitimately to disadvantage her opponent's case development. Such obstruction undermines the promotion of justice and the protection of clients' interests as much as the "sharp practices" envisioned by the Hickman Court.

\section{Availability of Other Remedies}

Moody also directed the district court to consider the availability of alternative sanctions as remedies for attorney misconduct. ${ }^{87}$ When the misconduct involves obtaining information about the case or disadvantaging an opponent's case preparation, the exception is the most appropriate remedy. When the misconduct does not affect the allocation of information between the parties, however, other sanctions should be used.

Where information is gathered through misconduct, the work product doctrine's purposes do not apply. Thus, the doctrine should not protect the materials. Although Moody suggests that courts should always consider the availability of other remedies, there is no need to do so when the information to be protected was gathered through misconduct. The work product doctrine's purpose was to protect information obtained through legitimate means, and should not apply to information gathered through illegitimate means. The misconduct exception should sometimes apply to documents containing information not obtained through misconduct, such as the index example above. ${ }^{88}$ In such cases, where disclosure of work product could correct misallocations of information resulting from misconduct, the purposes of the doctrine do apply, but those purposes are, on balance, better served by applying the exception. Here, a court should consider whether other remedies are available (either to deter the conduct or to remedy the need for the information) in deciding whether the doctrine's underlying policies are better served through protection or disclosure. If other remedies can serve to deter the misconduct and correct the information asymmetry, then there is no reason to ap-

\footnotetext{
so 329 US at $510-11$.

87 654 F2d at 801 .

${ }^{88}$ See text at notes $85-86$.
} 
ply the misconduct exception. Where disclosure will result in harm to parties other than the misbehaving attorney's client, a court should consider whether any other remedy, such as giving a party additional time to obtain the information or requiring the misbehaving attorney to pay the necessary costs of remedying the misconduct, would sufficiently address the misconduct. Alternative remedies should also be considered when applying the exception would result in the disclosure of information protected by other legal rules, such as trade secrets or attorney-client privileges.

\section{Interests of the Parties}

Finally, trial courts should consider the effect disclosure would have on all the parties to the litigation. Moody states that "the client's interest in preventing disclosures about his case may survive the misfortune of his representation by an unscrupulous attorney." client's legitimate interests in secrecy.

Unless the client has other protectable interests in the information, as in the case of protected attorney-client communications or trade secrets, the client's interests should not generally prevent application of the exception. ${ }^{90}$ Usually, where the information in question was obtained through misconduct, a client's assertion of legitimate secrecy concerns will seem implausible; the documents would not exist had the attorney not engaged in the misconduct. If the client could protect the materials, she would benefit from her attorney's unethical acts. The work product doctrine would then provide incentives to engage in unethical behavior. Indeed, the attorney might also benefit to the extent that she is able to extract a premium for engaging in such unethical practices.

Clients should bear the costs of their attorney's misconduct; to punish a client ${ }^{91}$ for the misconduct of her attorney is not inherently unfair, ${ }^{92}$ if for no other reason than that the client was re-

89 654 F2d at 801.

"0 As the Moody court noted, "In some cases, the extent to which a client should be allowed to benefit from unprofessionally obtained information may also be questioned; such benefits, in some cases, may not be deemed a 'legitimate' secrecy interest. Id at $801 \mathrm{n} 24$.

81 See In re Sutter, 543 F2d 1030, 1037 (2d Cir 1976) (where unfair to impose sanctions directly on the client, sanctions may be imposed upon the attorney); see also Renfrew, 67 Cal L Rev at 273 (cited in note 57).

${ }^{92}$ The attorney misconduct exception presupposes that the client is not involved in the misconduct. If the client were actively involved the fraud exception to the work product doctrine would vitiate the protection. See In re International Systems and Controls Corp. Securities Litigation, 693 F2d 1235, 1241-43 (5th Cir 1982); In re John Doe Corp., 675 F2d 
sponsible for bringing the misbehaving attorney into the litigation. $^{93}$ Moreover, sanctions that reach only the attorney will not always provide a sufficient remedy, such as where the client is allowed to benefit from the detrimental affect of the misconduct on the opponent. As between the client and the opposing party, the client should bear the cost of the misconduct. ${ }^{94}$ If the client is truly innocent of all wrongdoing, she may be able to recover damages from the attorney in a legal malpractice suit.95

While the exception allows a court to visit the sins of a misbehaving attorney on her client, it should not allow those sins to be imposed on other parties to the litigation. A judge should consider the effect disclosure might have on parties other than those battling over the documents. More specifically, the court should ensure that the forced production of work product will not have a detrimental effect on any parties whose interests are closely aligned with those of the misbehaving attorney's client. Although an attorney's client might rightfully be held responsible for the attorney's actions, no such rationale ordinarily supports holding other parties responsible for those actions. Protection of these parties' legal claims demands that they are not substantially disadvantaged as a result of conduct they could not control.

\section{Conclusion}

The work product doctrine seeks to establish the optimal balance between the benefits of liberal discovery and the benefits of the adversary system. Liberal discovery rules correct inequalities

\footnotetext{
482, 492-93 (2d Cir 1982).

${ }^{03}$ Renfrew, $67 \mathrm{Cal} \mathrm{L}$ Rev at 273-74 (cited in note 57).

" Id. ("[M]isconduct imposes costs, [] if someone must bear them the litigant who retained the offending attorney is most responsible.").

os Id at 274; Edna Selan Epstein, et al, An Up-Date on Rule 37 After National Hockey League v. Metropolitan Hockey Clubs, Inc., 84 FRD 145, 172-73 (1980). In addition, courts do hold that the client may be held responsible for the "sins of the lawyer." In Link $v$ Wabash Railroad, 370 US 626, 633-34 (1962) (quoting Smith v Ayer, 101 US 320, 326 (1879)), the Supreme Court stated:

Petitioner voluntarily chose this attorney as his representative in the action, and he cannot now avoid the consequences of the acts or omissions of this freely selected agent. Any other notion would be wholly inconsistent with our system of representative litigation, in which each party is deemed bound by the acts of his lawyer-agent and is considered to have "notice of all facts, notice of which can be charged upon the attorney."

Accord Pease o Peters, 550 F2d 698, 701 (1st Cir 1977) ("While we realize that the sins of the attorney are being visited upon the plaintiff, we must also recognize that the wheel of justice ... would grind to a halt if delays such as the one requested here were to be allowed.").
} 
in the access to information about events that took place before the onset of the litigation. The adversary system aims to protect information and strategies developed after litigation has commenced. Gathering information must, however, be done within the rules. The work product doctrine's purpose was to create incentives to gather information through legitimate avenues. Where misconduct results in the obtaining of information illegitimately, the work product doctrine's purposes are not served and the misconduct exception should be applied. The misconduct exception to the work product doctrine serves a useful function when it is applied to correct misallocations of information due to behavior that reaches beyond the rules. Where misconduct disadvantages the moving party in her ability to obtain relevant information, the four-step approach proposed by this Comment allows the judge to use the misconduct exception to redress this wrong, even if the materials do not contain information gathered through misconduct. A court should consider whether the attorney's conduct violated a law or accepted norm of professional conduct, whether the materials can correct an information asymmetry, whether other remedies can address the resulting information imbalance, and whether disclosure will adversely affect other parties. This formulation of the exception establishes the fair and efficient distribution of information envisioned by the discovery rules and the work product doctrine. By including misconduct that creates a disparity between the parties' costs of obtaining information, this Comment's approach offers courts a new method to remedy discovery abuses. In such cases, the court should order disclosure of the relevant work product in order to equalize the costs of the parties' access to information. 